Received Date : 08-Sep-2015

Revised Date : 19-Jan-2016

Accepted Date : 21-Jan-2016

Article type : Review Article

\title{
NUTRITION AND NEURODEVELOPMENTAL OUTCOMES IN PRETERM INFANTS: A SYSTEMATIC REVIEW
}

\begin{abstract}
Stephanie H T. Chan ${ }^{1}$, Mark J. Johnson ${ }^{2,3}$, Alison A. Leaf ${ }^{2,3}$, Brigitte Vollmer ${ }^{4,5}$
Affiliations: Faculty of Medicine, University of Southampton ; ${ }^{2} \mathrm{NIHR}$ Biomedical Research

Centre Southampton, University Hospital Southampton NHS Foundation Trust and

University of Southampton, ${ }^{3}$ Department of Neonatal Medicine, Southampton Children's

Hospital, University Hospital Southampton NHS Foundation Trust; ${ }^{4} \mathrm{Clinical}$ and Experimental

Sciences, Clinical Neurosciences, Faculty of Medicine, University of Southampton; ${ }^{5}$

Neonatal and Paediatric Neurology, Southampton Children's Hospital, University Hospital

Southampton NHS Foundation Trust
\end{abstract}

Correspondence to: Stephanie Chan, Faculty of Medicine, University of Southampton, stephanie.chan@doctors.org.uk

Short title: Nutrition and neurodevelopment in very preterm infants

Key Words: Very preterm, low birth weight, infant, nutrition, neurodevelopment

\section{ABSTRACT}

A systematic review with meta-analysis was carried out to investigate the effects of increased nutritional intake, via either macronutrient or multi-nutrient intervention, during the neonatal period on neurodevelopmental outcomes in infants born at $<32$ weeks of gestation or weighing $<1501 \mathrm{~g}$ at birth.

Conclusion: Although the relationship remains unclear, increased early nutrition may reduce neurodevelopmental impairment in this group of infants. Future research should focus on using standardised nutritional interventions and an agreed neurodevelopmental assessment battery.

This article has been accepted for publication and undergone full peer review but has not been through the copyediting, typesetting, pagination and proofreading process, which may lead to differences between this version and the Version of Record. Please cite this article as doi: 10.1111/apa.13344

This article is protected by copyright. All rights reserved. 
Key notes

- Increased early enteral nutrition may reduce neurodevelopmental impairment in very preterm and/or very low birth weight infants, but the direct relationship between neurodevelopmental outcome and nutrition remains unclear

- There is a lack of recent adequately powered studies on this topic

- Additional research is required and should focus on using standardised nutritional interventions and an agreed neurodevelopmental assessment battery, as the lack of homogeneity was a major limitation in this review

Adverse neurodevelopmental outcome is common in very preterm (VP) and very low birth weight (VLBW) infants(1, 2). Postnatal growth failure is also common in these infants(3). Epidemiological studies $(4,5)$ have shown that infants born extremely preterm are often lighter and have a smaller head circumference compared with published population norms at expected delivery date, despite being born with average weight and head circumference for their gestation. Neurodevelopmental outcomes of preterm infants are subject to multiple influences and it is likely that nutrition plays a key part. Furthermore, nutrition can be measured and modified, and so offers a potential intervention to improve outcomes. At the same time, it should be acknowledged that altering early nutrition in preterm infants could potentially result in changes to body composition and in turn the risk of obesity and noncommunicable disease in later life(6). Although there is evidence that in VLBW infants poor growth during the early postnatal period is associated with a higher incidence of neurodevelopmental impairment at toddler age(7), the findings of studies that have investigated the effect of early and/or increased nutrition in preterm infants have been inconsistent(8-10), and the evidence for nutritional interventions to improve neurodevelopmental outcome is unclear. We therefore carried out a systematic review to 
examine the effects of increased early nutritional intake on neurodevelopmental outcomes in infants born VP and/or with VLBW assessed at toddler age or during childhood.

\section{METHOD}

Study design

Studies were considered if they were randomised controlled trials (RCT), non-randomised control trials (NRCT), or observational studies. There were no restrictions on publication status, language, or year of publication.

Inclusion criteria

Studies that specifically compared an intervention providing increased nutrient intakes during the neonatal period (defined as first 28 days after birth) in infants born VP, $<32$ weeks of gestational age $(\mathrm{GA})$, or with birth weight $(\mathrm{BW})<1501 \mathrm{~g}$, with a control group receiving a 'standard' amount of nutrition, were eligible for inclusion. The intervention had to include higher quantity of nutrients over a defined period, such as consistently higher nutrient intakes in the intervention group compared to the control group, a difference in the increment of nutrient increase during the intervention period, or a difference in the length of intervention to provide a higher amount of nutrition overall. Nutritional interventions could be parenteral nutrition (PN), enteral nutrition (EN), or a combination of both. Studies were excluded if there was no documented protocol to increase nutrient intake, or if they focused on one single specific micronutrient.

\section{Outcome measures}

Outcome measures included neurodevelopmental outcome at 12-18 months, 24 months of corrected gestational age (CGA) (these ages of assessment hereafter referred to as toddler age) and/or at childhood as well as neurological status (presence or absence of Cerebral Palsy, CP). Since the Mental Developmental Index (MDI) and Psychomotor Developmental 
Index (PDI) subscales of the Bayley Scales of Infant Development Second edition(11) (BSIDII) are widely used, meta-analyses were based on these subscales. Studies that reported cognitive, language and motor subscales of Bayley Scales of Infant and Toddler Development Third edition(12) (Bayley III), were converted into MDI and PDI using Moore et al's method(13) to allow meta-analyses.

\section{Searches and information source}

A search was carried out by using the search strategy detailed in table 1 . The electronic databases MEDLINE, EMBASE and CINAHL were searched, with the last search carried out on 15th Jan 2015. Conference abstracts and other citations were identified using Web of Science. Reference searching was performed on articles that were selected for review.

\section{Study selection}

Studies were assessed for eligibility by two reviewers (SC and MJ) independently. Selection was on the basis of titles and abstracts where possible, with the full text obtained where necessary.

Data collection process

Data on study characteristics, nutritional interventions, nutritional intakes, and outcome measures (neurodevelopmental outcomes, morbidity and mortality) were collected using a study specific spreadsheet. Additional data were obtained from authors where required.

Risk of bias assessment

The quality of RCT and NRCT was assessed using the Cochrane Risk of Bias Assessment Tool(14), and observational studies were assessed using the Newcastle Ottawa Scale(15).

Synthesis of results

Parenteral nutrition and EN studies were analysed separately due to their relative timing of use during the neonatal period. Meta-analyses were performed where appropriate. Analysis was carried out using the software Review Manager v5.2(16). Heterogeneity was checked 
using $P$ statistic. A random effects model was used for all continuous data analyses. Peto's method was used to calculate a pooled odds ratio $(\mathrm{OR})$ for binary outcome data(17). When means and standard deviations (SD) were not provided, they were calculated using the method described by Hozo et al(18). Meta-regression was carried out using Stata version 12.1 (StataCorp LP). All statistical analyses were conducted by authors SC and MJ.

\section{RESULTS}

Study selection

The review process is demonstrated in figure 1. Eighteen papers, published between 1982 and 2014 that reported 15 studies, were included (10 RCT, 1 NRCT, and 4 retrospective observational studies). Three of the included studies reported follow-up findings from two RCTs.

Study characteristics

Characteristics of included studies are summarised in table 2. There were no significant differences in the mean $\pm S D$ of $G A(29.6 \pm 1.7$ vs $29.6 \pm 1.8$ weeks, $p=0.80)$ or birth weight (1226.8 $\pm 321 \mathrm{~g}$ vs $1234.7 \pm 322 \mathrm{~g}, \mathrm{p}=0.60)$ between the intervention and the control groups. Interventions varied between studies; five of the six PN trials investigated early delivery and increased content of protein (19-23), the remaining PN trial investigated increases in both micro- and macronutrients (24). Four of the seven EN studies investigated multi-nutrient supplementation to either maternal or donor breast milk(8-10, 25-28), two studies investigated protein supplementation to breast milk(29, 30), and one study compared protein enriched formula to standard formula(31). In addition to supplementation, Lucas et al also conducted trials that compared multi-nutrient enriched sole diet, containing preterm formula only, to either only donor breast milk(9) or only term formula(10), these intervention hereafter is referred to sole diet trials. In the two studies that investigated increasing both PN and EN, 
Tan et al(32) investigated the effect of hyperalimentation, where the intervention group received parenteral or/and enteral nutrition that contained macronutrients above the recommended amount, whereas Rochow et al(22) investigated the implementation of a feeding program.

\section{Quality assessment}

Assessments of quality and risk of bias in the controlled trials and observational studies are summarised in table 3A and 3B respectively. The potential risk of bias in studies was taken into consideration during data interpretation. Observational studies were presented separately to RCTs and NRCTs in meta-analyses. Of the four observational studies, only two studies $(21,24)$ adjusted for morbidities in their analysis. This is also shown in table 3B.

\section{Primary outcomes}

\section{Neurodevelopmental outcome}

Neurodevelopmental outcomes were reported in all included studies. Mental Developmental Index and PDI were reported in ten studies(8, 10, 19-21, 23, 26, 28, 30, 32). Knobloch et al's Developmental Inventory Quotients(33) were further reported in two studies(8, 9). Two studies reported subscales of Bayley III $(24,34)$. Cormack et al(24) reported scores on cognitive, language, and motor subscales which were also converted into MDI and PDI, and Burattini et al(34) reported Bayley III scores, but lack of details regarding individual subscales meant that MDI could not be calculated. Studies that reported MDI, PDI, or Bayley III subscales that allowed conversion to MDI at 12 to 18 months, were included in the metaanalysis. Other methods used to investigate neurodevelopment at toddler age included the Munich Functional Developmental Diagnostics(35) (MFED) test reported by Rochow et al(22), and the Griffiths Mental Development Scales(36) (GMDS) used by Biasini et al(29). Studies that investigated neurodevelopmental outcome in childhood and adolescence reported Verbal (VIQ) and Performance (PIQ) Intelligence Quotients, and Full Scale 
Intelligence Quotient (FSIQ) using either Wechsler Intelligence Scale for Children (revised anglicised version: WISCR- UK)(37, 38), or Wechsler Intelligence Scale for Children-Third edition (WISC-III)(39) or Wechsler Adult Intelligence Scale- Revised(WAIS-R)(25, 40).

Neurodevelopmental outcome at age 12-18 months: Results of meta-analysis

Meta-analysis of EN trials $(8,10,26,28,30)$, PN trials $(19-21,24)$ and two sole diet trials(10, 28) showed non-significant effects on MDI and PDI. A negative mean difference was observed in the meta-analysis of PN studies and MDI (figure 2), and although this was not statistically significant, this finding is consistent with meta-analysis at 24 months (figure 5). Significant heterogeneity was found in PDI in the meta-analysis of EN trials $\left(\mathrm{I}^{2}=95 \%\right.$, $\mathrm{p}<0.001)$ and sole diet trials $\left(\mathrm{I}^{2}=90 \%, \mathrm{p}<0.001\right)$, demonstrated in figure 3 and figure 4 , respectively.

Neurodevelopmental outcome at age 12-18 months: Results of meta-regression The relationship between early increased nutrition and neurodevelopmental outcome was further explored using meta-regression. Energy and protein were considered separately. There were no significant linear relationships between energy or protein and MDI or PDI for studies using PN. For EN studies, there was no significant linear relationship between protein or energy content and MDI at 12-18 months (regression coefficients 1.62 and -0.09 respectively, $p>0.5$ for both). While there was no significant linear relationship between increased EN protein and PDI (regression coefficient $-30.20, p=0.33$ ) there was a positive linear correlation between energy and PDI that approached significance (regression coefficient $0.75,95 \% \mathrm{Cl}:-0.05,1.54, \mathrm{p}=0.06)$. Although not statistically significant, this suggests that for every extra calorie per kg per day of enteral energy intake, there may be a 0.75 point increase in PDI.

Neurodevelopmental outcome at age 24 months: Results of meta-analysis Three PN studies $(19,23,34)$ reported neurodevelopmental outcomes at 24 months; only two were appropriate for meta-analysis. The remaining study, Burattini et al(34), reported 
only cognitive scales, and therefore MDI and PDI could not be calculated. Whilst Blanco et al(19) reported MDI and PDI at both 18 and 24 months, results were pooled into two different meta-analyses. The meta-analyses showed that increase in PN has a significant negative effect on MDI with a mean difference of -3.99 [(CI 95\%, -7.69 to -0.29$), p=0.03]$, but with no significant effect on PDI at 24 months (figure $5 \mathrm{~A}$ and $\mathrm{B}$ ).

Neurodevelopmental outcome: Results not included in meta-analysis

Tan et al(32) and Rochow et al(22) investigated increasing both EN and PN, and neither study reported significant effects on neurodevelopment at 3 and 9 months, or at 24 months, respectively.

Similarly, Burattini et al(34) found no significant differences in Bayley III scores at 24 months between infants who received increased amino acid intake and those who received standard amount from birth to day four.

Two EN studies that investigated increasing protein showed contrasting results(29, 31), Svenningsen et al(31) reported no group differences in neurodevelopmental outcomes at two years of age, whereas Basini et al(29) found that infants receiving additional protein performed better in the items of the GMDS at three months CGA (95.5 vs 109.8, $p=0.04$ ).

Long term cognitive outcomes were reported by two follow-up studies from the same original cohort. Lucas et al(27) reported no significant differences in the VIQ, PIQ and FSIQ at 7.5- 8 years of age between the intervention and control groups in both the sole diet trial and the supplementation trial. In contrast, Isaac et al(25) found that the mean \pm SD VIQ at the median age of 16 years was significantly higher in the intervention group compared to the control group from the same cohort $(102 \pm 14$ vs $94 \pm 11, p<0.01)$.

This article is protected by copyright. All rights reserved. 
Rate of survival without neurodevelopmental impairment:

Meta-analyses of the rate of survival without neurodevelopmental impairment were carried out on four $\mathrm{EN}(9,10,26,34,41)$ and four $\mathrm{PN}(20,21,23,34)$ studies. Meta-analyses revealed that infants who received increased EN were approximately twice as likely to survive without neurodevelopmental impairment compared to the infants who received a standard amount of nutrition, OR $1.89(1.24,2.73 ; p=0.003)$. No difference was found on meta-analysis of PN studies, OR $1.04(0.74,1.46 ; p=0.82)$, as demonstrated in figure 6 . Of note, one $\mathrm{RCT}(10)$ reported the incidence of $\mathrm{MDI}<70$ and $\mathrm{PDI}<70$ seperately, rather than the number of infants with neurodevelopmental impairment (defined as either MDI or PDI being less than 70). Therefore, in order to be included in the meta-analysis, the total number of infants with either $\mathrm{MDI}<70$ and PDI $<70$ were combined to give a total number of infants with impairment, though the actual number of infants with neurodevelopmental impairment may be overestimated in comparison to the other included studies, as some infants with both a MDI $<70$ and PDI < 70 will have been double counted.

\section{Secondary outcomes}

\section{Neurological outcome}

Four RCTs and two observational studies reported the rate of CP. Meta-analyses of two EN trials $(27,28)$, four PN trials $(19-21,23)$, and two sole diet trials $(12,28)$ showed no significant difference in incidence of $\mathrm{CP}$, with $\mathrm{OR}$ of $0.84(0.44,1.6 ; p=0.59), 1.06(0.68,1.63 ; p=$ $0.66)$ and $1.6(0.56,4.55)$, respectively.

Rate of neurodevelopmental impairment at toddler age: Results of meta-analysis Definitions of neurodevelopmental impairment differed across studies. Meta-analysis of three PN trials $(20,21,23)$ (which defined impairment as at least one of the following: MDI or PDI $<70$, presence of $\mathrm{CP}$, hearing loss or blindness) showed no significant differences in the 
rates of neurodevelopmental impairment at $18-24$ months with an $\mathrm{OR}$ of $1.10(0.78,1.56 ; \mathrm{p}=$ $0.58)$.

Rate of neurodevelopmental impairment: Results not included in meta-analysis

Of the remaining studies that reported neurodevelopmental impairment $(9,10,26,27,29)$, only one RCT, Lucas et al 1990(10), and its follow-up(27), reported a significantly higher incidence in the group that received standard nutrition, with a significantly lower incidence of psychomotor impairment (defined as PDI < 86) in the group that received increased nutrition at 18 months. The follow-up study also reported a significantly lower rate of cognitive impairment $(\mathrm{VIQ}<85)$ at $7.5-8$ years in a combined cohort of infants that received either increased EN via sole diet or supplementation. This remained statistically significant after adjusting for $\mathrm{CP}(27)$.

\section{DISCUSSION}

This review found that increased PN, particularly increased amino acid intake in the early period after birth, may result in sub-optimal neurodevelopmental outcomes at 24 months CGA. However, only two studies could be pooled in the meta-analysis (figure 5) due to the variation in outcomes measures and data reporting, therefore this finding requires confirmation through further research. On the other hand, importantly, the review also suggests that increased enteral nutrition may result in increased numbers of very preterm and/or very low birthweight infants surviving without neurodevelopmental impairment. A speculative explanation for such findings is that the omission of infants who did not survive for neurodevelopmental assessment and were thus omitted from the meta-analyses, may have confounded the results. By including survival in the outcome as 'survival without neurodevelopmental impairment', we were able to adjust for this possible confounding effect, and have shown that higher PN intake does not increase the likelihood of neurodevelopmental impairment in preterm infants. With regard to the negative outcome 
from early increased amino acid intake seen in Blanco et al's study, it is important to consider that this could be related to the specific composition of the amino acid solution, rather than to overall intake of protein. Therefore, findings from this study may not be generalisable to other studies with early increased amino acid interventions. Additionally, this study has a high attrition rate with the fewest participants $(n=16)$ in the meta-analysis at 24 months. Overall, our review showed no significant effects from increased nutrition on the rates of $\mathrm{CP}$.

Meta-regression did not provide additional information on the relationship between nutritional intake and neurodevelopment, but individual studies from this review have demonstrated significant associations. In a retrospective observational study which investigated increased parenteral nutrition via multi-nutrient intervention, Cormack et al(24), found that mean enteral protein intake during the first two postnatal weeks had a positive association with cognitive $\left(r^{2}=0.13, p=0.03\right)$ and motor subscales $\left(r^{2}=0.27, p=0.001\right)$ of Bayley III at 18 months CGA. Similarly, Stephens et al(42) reported a positive association between average energy and protein intake in the first week after birth and MDI at 18 months CGA. In addition, nutritional deficits at 28 days after birth were found to be negatively associated with neurodevelopment at 3 months. Tan et al (32) calculated energy and protein deficit at 28 days after birth by subtracting actual daily intakes from recommended intakes of 120 $\mathrm{kcal} / \mathrm{kg} /$ day of energy and $3 \mathrm{~g} / \mathrm{kg} /$ day of protein. Energy and protein deficit significantly correlated with $\mathrm{MDI}(R=-20.25, p=0.03$ and $R=-20.32, p=0.004$, respectively $)$, and PDI $(R=-20.29, p=0.01$ and $R=-20.3, p=0.006$, respectively $)$

Longer term outcome was reported in two studies of the same RCT cohort, but with inconclusive findings $(25,27)$. Lucas et al(27) reported a small, but non-significant, advantage in VIQ and PIQ at 7.5-8 years of age in the multi-nutrient supplementation trial, and Isaacs et al(25) also reported significantly higher VIQ at 16 years of age in the higher 
nutrient group. However, the reported confidence interval was contradictory to the $p$-value $(\mathrm{Cl}:-14,12 ; \mathrm{p}<0.01)$, thus the significance is unclear.

Although our review has not specifically explored the effects of gender, several studies have suggested that early increased nutrition may have greater beneficial effects on premature boys than girls. Van den Akker et al demonstrated that preterm male infants are six times more likely to have normal outcomes with parenteral nutritional intervention compared to preterm female infants [adjusted odds ratio $=6.17,95 \% \mathrm{Cl}(1.01-38.46)$ ]. This was similar

to the studies by Lucas et al, who observed greater impact of increased early enteral nutrition on neurodevelopment in male than female preterm infants throughout their series of RCTs and follow-up studies. Substantial effects from enteral supplementation on mental and motor development in males compared to females were found particularly at the 18 month CGA follow-up. Brain development is different between male and female, and it has been suggested that this may influence the periods of maximal sensitivity to environmental factors such as nutrition.

Significant heterogeneity was found across the meta-analyses. The meta-analysis for PN trials and MDI at $12-18$ months showed significant heterogeneity $\left(I^{2}=75.9 \%\right)$ between the study designs. The only RCT that was pooled into this meta-analysis demonstrated significant negative findings within the subgroup analysis, however, this study included the smallest sample size and when combined with observational studies, the mean difference became statistically non-significant. Similarly, meta-analysis of EN studies and PDI at 12-18 months CGA showed $I^{2}=95 \%$, where significant benefits were described by two of the five studies, with Lucas et al(10) reporting the greatest effect. Although this study (10) was assessed to contain low risk of bias, it was conducted more than two decades ago, and further studies in a more contemporary sample may strengthen the evidence for the conclusion made in this study. Likewise, the reviewed literature is dominated by research published over a decade ago, and there is a lack of recent adequately powered studies on 
this topic. Recent trials that were included were predominately single centered. Results of larger multi-centered studies investigating neurodevelopmental outcome as a primary or secondary outcome are not currently available.

A considerable amount of variation in the type of interventions, outcomes, and age at assessment was found across the studies, particularly in the EN trials. The components of nutritional interventions differed markedly between studies. The proportion of mother's breast milk and supplementation used in individual trials was also not controlled except in one of the supplement trials(9). Consequently, the actual effect of increased nutrition might not be fully reflected in these studies. Another major limitation in the data is that not all the studies reported whether the actual nutritional intervention was achieved, and for the 11 studies that have reported this, only 4 studies achieved the intended nutrient intakes.

While this review supports the concept that early nutrition is important for optimal neurodevelopment, it provides no clarity on which specific nutrients or clusters of nutrients might be beneficial - or potentially harmful. Furthermore, the recommended nutritional intakes for preterm infants have changed over the last two decades, and this is demonstrated by the significant variations between the nutrition interventions in studies published at different times over the past 20 years or so (see table S1). The older studies appear to provide smaller amounts of nutrition in their control groups compared to more recent studies. When the standard nutrition is below optimal, providing more nutrition may be beneficial; however, providing nutrition above the optimal level may not be beneficial and may even be harmful.

Nutrition is complex and it is likely that there is a pattern of optimal intake of multiple nutrients, including energy, amino acids and micro-nutrients, which must be balanced with metabolic capacity. Including neurodevelopment as an outcome measure to identify these intakes is vitally important. In addition to nutrition, other contributing factors such as

This article is protected by copyright. All rights reserved. 
intrauterine toxins and infections, maternal co-morbidities, genetic factors and many other variables could not be considered in this review.

\section{CONCLUSION}

This study provides a comprehensive review of the published evidence for the effects of increased early nutrition, either via increased macronutrients or multi-nutritional intervention, on neurodevelopmental outcome in VP and/or VLBW infants at toddler age and in childhood. The review has shown that increased early nutrition may increase the likelihood of survival without neurodevelopmental impairment in VP and/or VLBW infants, but the direct relationship between neurodevelopmental outcome and nutrition after birth remains unclear. Whilst early nutritional interventions may be beneficial for neurodevelopment, optimal nutritional regimens are still not defined, and as such there is a need for additional research in this field. Further research should follow the Core Outcome Measures in Effectiveness Trials initiative(43) to develop a core set of agreed standardised outcomes. This will facilitate data synthesis for future systematic reviews, as the lack of homogeneity was a major limitation in this review.

CONFLICT OF INTEREST AND FUNDING This work was primarily carried out as part of a medical student MMedSc project by SC at the University of Southampton and did not receive any specific funding.

\section{Abbreviations:}

Bayley III- Bayley Scales of Infant and Toddler Development - Third edition

BSID II- Bayley Scales of Infant Development - Second edition

BW- birth weight

CGA- corrected gestational age

CLD- chronic lung disease 
CP- cerebral palsy

ELBW- extremely low birth weight

EN- enteral nutrition

FSIQ- Full Scale Intelligence Quotient

GA- gestational age

GMDS- Griffiths Mental Development Scales

$\mathrm{IVH}$ - intraventricular haemorrhage

MDI- Mental Developmental Index

MFED- Munich Functional Developmental Diagnostic test

NEC- necrotising enterocolitis

NRCT- non randomised controlled trial

OR- odds ratio

PDI- Psychomotor Developmental Index

PIQ- Performance Intelligence Quotient

$\mathrm{PN}$ - parenteral nutrition

RCT- randomised controlled trial

SD- standard deviation

VIQ- Verbal Intelligence Quotient

VLBW- very low birth weight

VP- very preterm

WAIS-R- Wechsler Adult Intelligence Scale-Revised

WISC-III- Wechsler Intelligence Scale for Children - Third edition

WISC-R- Wechsler Intelligence Scale for Children - Revised

References:

1. Saigal S, Doyle LW. An overview of mortality and sequelae of preterm birth from infancy to adulthood. Lancet 2008;371:261-9.

2. Delobel-Ayoub M, Arnaud C, White-Koning M, Casper C, Pierrat V, Garel M et al. Behavioral problems and cognitive performance at 5 years of age after very preterm birth: the EPIPAGE Study. Pediatrics 2009;123:1485-92.

3. Ehrenkranz RA. Early nutritional support and outcomes in ELBW infants. Early Hum Dev 2010;86 Suppl 1:21-5.

This article is protected by copyright. All rights reserved. 
4. Wood N, Costeloe K, Gibson A, Hennessy E, Marlow N, Wilkinson A. The EPICure study: growth and associated problems in children born at 25 weeks of gestational age or less. Arch Dis Child Fetal Neonatal Ed 2003;88:F492-F500.

5. Costeloe KL, Hennessy EM, Haider S, Stacey F, Marlow N, Draper ES. Short term outcomes after extreme preterm birth in England: comparison of two birth cohorts in 1995 and 2006 (the EPICure studies). Bmj 2012;345:e7976.

6. Johnson MJ, Wootton SA, Leaf AA, Jackson AA. Preterm birth and body composition at term equivalent age: a systematic review and meta-analysis. Pediatrics 2012;130:e640-9.

7. Ehrenkranz RA, Dusick AM, Vohr BR, Wright LL, Wrage LA, Poole WK. Growth in the neonatal intensive care unit influences neurodevelopmental and growth outcomes of extremely low birth weight infants. Pediatrics 2006;117:1253-61.

8. Lucas A, Fewtrell MS, Morley R, Lucas PJ, Baker BA, Lister G et al. Randomized outcome trial of human milk fortification and developmental outcome in preterm infants. Am J Clin Nutr 1996;64:142-51.

9. Lucas A, Morley R, Cole TJ, Gore SM, Davis JA, Bamford MF et al. Early diet in preterm babies and developmental status in infancy. Arch Dis Child 1989;64:1570-8.

10. Lucas A, Morley R, Cole TJ, Gore SM, Lucas PJ, Crowle P et al. Early diet in preterm babies and developmental status at 18 months. Lancet 1990;335:1477-81.

11. Bayley N. Bayley Scales of Infant Development. Psychological Corporation. 2nd ed. San Antonio, TX. 1993.

12. Bayley N. Bayley Scales of Infant and Toddler Development. Harcourt Assessment 3rd ed. San Antonio, TX. 2006.

13. Moore T, Johnson S, Haider S, Hennessy E, Marlow N. Relationship between test scores using the second and third editions of the Bayley Scales in extremely preterm children. J Pediatr 2012;160:553-8.

14. Higgins J, Green, S. Cochrane Handbook for Systematic Reviews of Interventions Version 5.1.0 [Updated March 2011]. The Cochrane Collaboration 2011.

15. Wells GA, Shea B, O' Connell D, Peterson J, Welch V, Losos M et al. The Newcastle-Ottawa Scale (NOS) for assessing the quality if nonrandomized studies in meta-analyses. Ottawa (ON). Ottawa Health Research Institute 1999.

16. Review Manager (RevMan). Version 5.2. Copenhagen: The Nordic Cochrane Centre: The Cochrane Collaboration; 2008.

17. Bradburn MJ, Deeks JJ, Berlin JA, Russell Localio A. Much ado about nothing: a comparison of the performance of meta-analytical methods with rare events. Stat Med 2007;26:53-77.

18. Hozo S, Djulbegovic B, Hozo I. Estimating the mean and variance from the median, range, and the size of a sample. BMC Medical Research Methodology 2005;5:13.

19. Blanco CL, Gong AK, Schoolfield J, Green BK, Daniels W, Liechty EA et al. Impact of early and high amino acid supplementation on ELBW infants at 2 years. J Pediatr Gastroenterol Nutr 2012;54:601-7.

20. Karakus F, Türker G, Gökalp AS. The effect of early parenteral amino acids, on growth and neurodevelopment of very low birth weight infants [Turkish]. Turkish Pediatrics Archive 2010;45:111-8.

21. Poindexter BB, Langer JC, Dusick AM, Ehrenkranz RA. Early provision of parenteral amino acids in extremely low birth weight infants: Relation to growth and neurodevelopmental outcome. $J$ Pediatr 2006;148:300-.e7.

22. Rochow N, Fusch G, Muhlinghaus A, Niesytto C, Straube S, Utzig N et al. A nutritional program to improve outcome of very low birth weight infants. Clin Nutr 2012;31:124-31.

23. van den Akker $\mathrm{CH}$, te Braake FW, Weisglas-Kuperus N, van Goudoever JB. Observational outcome results following a randomized controlled trial of early amino acid administration in preterm infants. J Pediatr Gastroenterol Nutr 2014;59:714-9.

This article is protected by copyright. All rights reserved. 
24. Cormack BE, Bloomfield FH, Dezoete A, Kuschel CA. Does more protein in the first week of life change outcomes for very low birthweight babies? J Paediatr Child Health 2011;47:898-903.

25. Isaacs EB, Gadian DG, Sabatini S, Chong WK, Quinn BT, Fischl BR et al. The effect of early human diet on caudate volumes and IQ. Pediatr Res 2008;63:308-14.

26. Kocourkova I, Sobotkova D, Pilarova M, Dittrichova J, Vondracek J, Stranak Z. [Effect of early nutrition on growth parameters and psychomotor development of children of very low birth weight]. Ceska Gynekol 2004;69 Suppl 1:108-13.

27. Lucas A, Morley R, Cole TJ. Randomised trial of early diet in preterm babies and later intelligence quotient. Bmj 1998;317:1481-7.

28. Lucas A, Morley R, Cole TJ, Gore SM. A randomised multicentre study of human milk versus formula and later development in preterm infants. Arch Dis Child Fetal Neonatal Ed 1994;70:F141-6. 29. Biasini A, Marvulli L, Neri E, China M, Stella M, Monti F. Growth and neurological outcome in ELBW preterms fed with human milk and extra-protein supplementation as routine practice: Do we need further evidence. Journal of Maternal-Fetal and Neonatal Medicine 2012;25:64-6.

30. Ergenekon E, Hirfanoglu I, Soysal S, Gucuyener K, Bas V, Turan O et al. Short and longterm effects of individualized enteral protein supplementation in preterm newborns. Journal of MaternalFetal and Neonatal Medicine 2012;25:135.

31. Svenningsen NW, Lindroth $\mathrm{M}$, Lindquist B. A comparative study of varying protein intake in low birthweight infant feeding. Acta Paediatr Scand Suppl 1982;296:28-31.

32. Tan M, Abernethy L, Cooke R. Improving head growth in preterm infants--a randomised controlled trial II: MRI and developmental outcomes in the first year. Arch Dis Child Fetal Neonatal Ed 2008;93:F342-6.

33. Knobloch H, Pasamanick B, Sherard ES. A developmental screening inventory for infants Pediatrics 1966;38:viii-1.

34. Burattini I, Bellagamba MP, Spagnoli C, D'Ascenzo R, Mazzoni N, Peretti A et al. Targeting 2.5 versus $4 \mathrm{~g} / \mathrm{kg} /$ day of amino acids for extremely low birth weight infants: a randomized clinical trial. J Pediatr 2013;163:1278-82.e1.

35. Hellbrügge T. Munich functional developmental diagnosis for the first, second, and third year of life. Theodor Hellbruegge International Institute for Developmental Rehabilitation. Kerala. 1995.

36. Griffith R. The Griffths mental developmental scales from birth to two years, manual, the 1996 version. Association for Research in infant and Child Development. Henley, Test Agency.1996. 37. Psychological Corporation. Wechsler intelligence scale for children, Anglicised. Rev ed. Sidcup. Rev ed. Sidcup: Psychological Corporation 1974.

38. Lucas A. Programming by early nutrition: an experimental approach. J Nutr 1998;128:401S-

$6 \mathrm{~S}$.

39. Wechsler Intelligence Scale for Children. 3rd ed. Sidcup, Kent: The Psychological Corporation; 1992.

40. Wechsler D. Wechsler Adult Intelligence Scale. 3rd ed. London: The Psychological Corporation; 1997.

41. Biasini A, Neri C, China MC, Monti F, Di Nicola P, Bertino E. Higher protein intake strategies in human milk fortification for preterms infants feeding. Auxological and neurodevelopmental outcome. J Biol Regul Homeost Agents 2012;26:43-7.

42. Stephens BE, Walden RV, Gargus RA, Tucker R, McKinley L, Mance M et al. First-week protein and energy intakes are associated with 18-month developmental outcomes in extremely low birth weight infants. Pediatrics 2009;123:1337-43.

43. Williamson P, Altman D, Blazeby J, Clarke M, Devane D, Gargon E et al. Developing core outcome sets for clinical trials: issues to consider. Trials 2012;13:132.

This article is protected by copyright. All rights reserved. 


\begin{tabular}{|c|c|}
\hline & Search terms \\
\hline & exp Infant, Very Low Birth Weight/ or exp \\
\hline 1 & Infant, Newborn/ or exp Infant, Premature/ \\
\hline & or exp Infant, Extremely Low Birth Weight/ \\
\hline 2 & preterm.mp. \\
\hline 3 & prematur*.mp. \\
\hline 4 & neonat ${ }^{\star} . m p$. \\
\hline 5 & 1 or 2 or 3 or 4 \\
\hline 6 & exp Nutrition Therapy/ or exp Enteral \\
\hline & Nutrition/ or exp Parenteral Nutrition, Total/ \\
\hline & Nutrition/ \\
\hline 7 & exp Child Development/ \\
\hline 8 & exp Neurologic Examination/ \\
\hline 9 & (cerebral adj palsy).mp. \\
\hline 10 & exp Cerebral Palsy/ \\
\hline 11 & disabilit*.mp. \\
\hline 12 & neurodevelopment*.mp. \\
\hline 13 & bayley.mp. \\
\hline 14 & (mental adj development).mp. \\
\hline 15 & (psychomotor adj development).mp. \\
\hline 16 & (motor adj scales).mp \\
\hline 17 & (language adj scales).mp. \\
\hline 18 & (cognitive adj scales).mp \\
\hline 19 & $\begin{array}{l}7 \text { or } 8 \text { or } 9 \text { or } 10 \text { or } 11 \text { or } 12 \text { or } 13 \text { or } 14 \text { or } \\
15 \text { or } 16 \text { or } 17 \text { or } 18\end{array}$ \\
\hline 20 & 5 and 6 and 19 \\
\hline 21 & limit 20 to Humans \\
\hline
\end{tabular}

Table 1: Search terms and strategy used for electronic searches ${ }^{1}$

${ }^{1}$ Performed by using OvidSp (Wolters Kluwer Health; http://www.ovid.com). adj, adjacent to; exp, exploded Medical Subject Headings term; .mp., multipurpose search across the fields title, abstract, subject headings, heading word, drug trade name, original title, device manufacturer, and drug manufacturer.

This article is protected by copyright. All rights reserved. 


\begin{tabular}{|c|c|c|c|c|c|c|c|c|c|c|}
\hline \multirow{2}{*}{ Author, year } & \multirow{2}{*}{$\begin{array}{l}\text { Study } \\
\text { type }\end{array}$} & \multirow{2}{*}{$\begin{array}{l}\text { PN } \\
\text { or } \\
\text { EN }\end{array}$} & \multicolumn{2}{|c|}{$\mathbf{N}$} & \multirow{2}{*}{$\begin{array}{c}\text { Gestation } \\
\text { al age } \\
\text { (weeks) }\end{array}$} & \multirow{2}{*}{$\begin{array}{l}\text { Birth } \\
\text { weight } \\
\text { (g) }\end{array}$} & \multicolumn{2}{|c|}{ Nutrition content } & \multirow{2}{*}{$\begin{array}{c}\text { Start of } \\
\text { intervention }\end{array}$} & \multirow{2}{*}{$\begin{array}{l}\text { Duration of } \\
\text { intervention }\end{array}$} \\
\hline & & & $\begin{array}{c}\text { Inter- } \\
\text { vention }\end{array}$ & Control & & & Intervention & Control & & \\
\hline Lucas1996(8) & $\mathrm{RCT}$ & EN & 137 & 138 & 29.8 & 1285 & Multinutrient supplement to MBM* & Control supplement to $\mathrm{MBM}^{*}$ & $48-72 \mathrm{hrs}$ & $39 d$ \\
\hline Lucas 1989a(9) & $\mathrm{RCT}$ & EN & 76 & 83 & 31.2 & 1378 & PTF sole diet* & DBM sole diet* & $<48 \mathrm{hrs}$ & $30 d$ \\
\hline Lucas $1989 b(9)$ & $\mathrm{RCT}$ & EN & 173 & 170 & 30.8 & 1386 & PTF supplement to MBM* & DBM supplement to MBM* & $<48 \mathrm{hrs}$ & $30 d$ \\
\hline Lucas 1994a(28) & FU & EN & 76 & 83 & 31.3 & 1400 & PTF sole diet* & DBM sole diet* & $<48 \mathrm{hrs}$ & $30 d$ \\
\hline Lucas $1994 b(28)$ & FU & EN & 173 & 170 & 31.1 & 1388 & PTF supplement to MBM* & DBM supplement to MBM* & $<48 \mathrm{hrs}$ & $30 d$ \\
\hline Lucas 1990a(10) & $\mathrm{RCT}$ & EN & 81 & 79 & 30.8 & 1372 & PTF sole diet* & Term formula sole diet $^{\star}$ & $<48 \mathrm{hrs}$ & $28 d$ \\
\hline Lucas 1990b(10) & $\mathrm{RCT}$ & EN & 132 & 132 & 31.2 & 1427 & PTF supplement to MBM* & Term formula supplement to $\mathrm{MBM}^{\star}$ & $<48 \mathrm{hrs}$ & $28 d$ \\
\hline Lucas 1998a(27) & FU & EN & 67 & 68 & 30.8 & 1379 & PTF sole diet* & Term formula sole diet ${ }^{*}$ & $<48 \mathrm{hrs}$ & $28 d$ \\
\hline Lucas 1998b(27) & FU & EN & 112 & 113 & 31.3 & 1425 & PTF supplement to MBM* & Term formula supplement to $\mathrm{MBM}^{\star}$ & $<48 \mathrm{hrs}$ & $28 d$ \\
\hline Isaacs $2008(25)$ & FU & EN & 38 & 38 & 28.7 & 1216 & PTF supplement to MBM* & Term formula supplement to $\mathrm{MBM}^{\star}$ & $<48 \mathrm{hrs}$ & $28 d$ \\
\hline Tan 2008(32) & $\mathrm{RCT}$ & Both & 68 & 74 & 26.1 & 913 & Hyperalimentated diet ${ }^{\star}$ & Control diet ${ }^{\star}$ & $<7 d$ & $7 d$ \\
\hline Biasini 2012(29) & $\mathrm{RCT}$ & EN & 19 & 13 & 28.1 & 976 & $\begin{array}{c}\text { Protein enriched supplement to } \\
\mathrm{MBM}^{*}\end{array}$ & Control supplement to $\mathrm{MBM}^{*}$ & At full EN & $34 d$ \\
\hline Blanco 2012(19) & $\mathrm{RCT}$ & PN & 30 & 31 & 26.4 & 813 & $2 \mathrm{~g} / 1 \mathrm{~g}$ until $4 \mathrm{~g}$ Protein in $\mathrm{PN}$ & $0.5 \mathrm{~g} / 0.5 \mathrm{~g}$ until $3 \mathrm{~g}$ Protein in $\mathrm{PN}$ & 24-36 hours & $7 d$ \\
\hline Ergenekon 2012(30) & $\mathrm{RCT}$ & EN & 33 & 32 & 30.3 & 1361 & $\begin{array}{c}\text { Protein supplement to fortified } \\
\text { MBM/PTF* }\end{array}$ & $\begin{array}{c}\text { Control supplement to fortified } \\
\text { MBM/PTF* }\end{array}$ & At full EN & Unknown \\
\hline Svenningsen 1982(31) & $\mathrm{RCT}$ & EN & 16 & 18 & 30.6 & 1348 & Protein enriched formula* & Control formula* & Soon After birth & $28 d$ \\
\hline Kocourkova 2004(26) & NRCT & EN & 22 & 17 & 30.8 & 1307 & Fortified DBM* & $\mathrm{MBM}^{*}$ & $<7 d$ & $56 d$ \\
\hline Cormack 2011(24) & Obs & PN & 49 & 40 & 27 & 920 & $\begin{array}{c}\text { Reformulated nutrient enriched } \\
\text { PN }^{\star}\end{array}$ & Previous $\mathrm{PN}^{*}$ & Soon After birth & $7 d$ \\
\hline Poindexter 2006(21) & Obs & PN & 182 & 836 & 26.1 & 798 & $>3.5 \mathrm{~g} / \mathrm{kg} / \mathrm{d}$ Protein PN & $<3.5 \mathrm{~g} / \mathrm{kg} / \mathrm{d}$ Protein PN & After birth & $5 d$ \\
\hline Karakus 2010(20) & Obs & PN & 31 & 45 & 29.2 & 1146 & 1g/1g until 3.5-4g Protein in PN & $0.5 \mathrm{~g} / 0.5 \mathrm{~g}$ until $3.5 \mathrm{~g}$ Protein in $\mathrm{PN}$ & Day 2 & $5 d$ \\
\hline Rochow 2012(22) & Obs & Both & 123 & 115 & 28.9 & 1070 & After feeding implementation* & Before feeding implementation* & From birth & $\begin{array}{c}\text { Approx. } 7 \text { wks } \\
\text { (intervention unti } \\
36 \text { wk PMA) }\end{array}$ \\
\hline Burattini 2013(34) & $\mathrm{RCT}$ & PN & 56 & 58 & 28.7 & 984 & $2.5 \mathrm{~g} / \mathrm{kg} / \mathrm{d}$ at $\mathrm{d} 1$ to $4 \mathrm{~g} / \mathrm{kg} / \mathrm{d}$ at $\mathrm{d} 4$ & $1.5 \mathrm{~g} / \mathrm{kg} / \mathrm{d}$ at $\mathrm{d} 1$ to $2.5 \mathrm{~g} / \mathrm{kg} / \mathrm{d}$ at $\mathrm{d} 4$ & $<24$ hours & $10 d$ \\
\hline
\end{tabular}

This article is protected by copyright. All rights reserved. 
Table 2. Characteristics of included studies; EN: enteral nutrition, PN: parenteral nutrition, RCT: randomised controlled trial, FU: Follow Up study, NRCT: non randomised controlled trial, Obs: Observational Study, MBM: maternal breast milk, DBM: donor breast milk, PTF: preterm formula, d: day; PMA: Post Menstrual Age

*See supplementation table

\begin{tabular}{|c|c|c|c|c|c|c|}
\hline Study & $\begin{array}{c}\text { Sequence } \\
\text { generation }\end{array}$ & $\begin{array}{c}\text { Allocation } \\
\text { concealment }^{2}\end{array}$ & $\begin{array}{l}\text { Blinding- } \\
\text { personnel }^{3}\end{array}$ & Blinding-outcomes ${ }^{4}$ & $\begin{array}{c}\text { Incomplete } \\
\text { outcome data }^{5}\end{array}$ & $\begin{array}{l}\text { Selective outcome } \\
\text { reporting }\end{array}$ \\
\hline Lucas 1996(8) & low & low & low & low & low & low \\
\hline Lucas 1989(9) & low & low & high & low & low & low \\
\hline Lucas 1994(28) & low & low & high & low & low & moderate \\
\hline Lucas 1990(10) & low & low & low & low & low & low \\
\hline Lucas 1998(27) & low & low & low & low & low & low \\
\hline Isaacs et al 2008(25) & unclear & low & low & low & low & low \\
\hline $\operatorname{Tan} 2008(32)$ & low & low & high & high & low & low \\
\hline Biasini 2012(29) & unclear & unclear & unclear & unclear & unclear & low \\
\hline Blanco 2012(19) & low & low & unclear & low & low & low \\
\hline Ergenekon 2012(30) & unclear & unclear & unclear & unclear & unclear & unclear \\
\hline Svenningsen $1982(31)$ & unclear & low & unclear & unclear & unclear & unclear \\
\hline Kocourkova 2004(26) & low & high & high & unclear & unclear & Low \\
\hline Burattini 2013(34) & low & low & high & low & low & Low \\
\hline Van Den Akker(23) & unclear & unclear & low & unclear & low & low \\
\hline
\end{tabular}

Table 3A. The level of apparent bias in included RCTs as assessed using the Cochrane risk of bias assessment tool

1. Selection bias due to inadequate generation of a randomised sequence.

2. Selection bias due to inadequate concealment of allocation prior to assignment.

3. Performance bias due to knowledge of the allocated interventions by personnel during the study.

4. Detection bias due to knowledge of the allocated interventions by outcome assessors.

5. Attrition bias due to the amount, nature or handling of incomplete data.

6. Reporting bias due to selective outcome reporting.

This article is protected by copyright. All rights reserved. 


\begin{tabular}{|c|c|c|c|c|c|c|c|c|}
\hline Study & $\begin{array}{l}\text { Representa- } \\
\text { tiveness of } \\
\text { exposed cohort }\end{array}$ & $\begin{array}{l}\text { Selection of } \\
\text { the non- } \\
\text { exposed } \\
\text { cohort }^{2}\end{array}$ & $\begin{array}{l}\text { Ascertain- } \\
\text { ment of } \\
\text { exposed } \\
\text { cohort }_{3}\end{array}$ & $\begin{array}{l}\text { Outcome not } \\
\text { present at start } \\
\text { of study }\end{array}$ & $\begin{array}{l}\text { Compara-bility } \\
\text { of cohorts }\end{array}$ & $\begin{array}{l}\text { Assess-ment } \\
\text { of outcome }\end{array}$ & $\begin{array}{l}\text { Follow-up long } \\
\text { enough for } \\
\text { outcome to occur }\end{array}$ & $\begin{array}{l}\text { Adequacy of } \\
\text { follow up }\end{array}$ \\
\hline $\begin{array}{l}\text { Cormack } 2011(24) \\
\text { Poindexter } 2006(21) \\
\text { Karakus } 2010(20) \\
\text { Rochow } 2012(22)\end{array}$ & $\begin{array}{l}+ \\
+ \\
+ \\
+\end{array}$ & $\begin{array}{l}+ \\
+ \\
+ \\
+\end{array}$ & $\begin{array}{l}+ \\
+ \\
+ \\
+\end{array}$ & $\begin{array}{l}+ \\
- \\
+ \\
+\end{array}$ & $\begin{array}{l}+ \\
+ \\
- \\
-\end{array}$ & $\begin{array}{l}- \\
+ \\
- \\
-\end{array}$ & $\begin{array}{l}+ \\
+ \\
+ \\
+\end{array}$ & $\begin{array}{l}+ \\
+ \\
+ \\
-\end{array}$ \\
\hline
\end{tabular}

Table 3B. Quality assessment of observational studies using Newcastle Ottawa Scale.

1. Truly or somewhat representative (+) Selected group of user or no description (-)

2. Drawn from same community as the exposed (+) Drawn from different source or no description(-)

3. Secure record or structured interview(+) written self report or no description (-)

4. Yes (+) No (-)

5. Controls for baseline weight (+) controls for any factors (+) Does not control for any factor (-)

6. Independent blind assessment or record linkage (+) self report or no description (-)

7. Complete follow up all subject accounted for or minimal lost unlikely to introduce bias (+) No description or statement (-)

This article is protected by copyright. All rights reserved. 


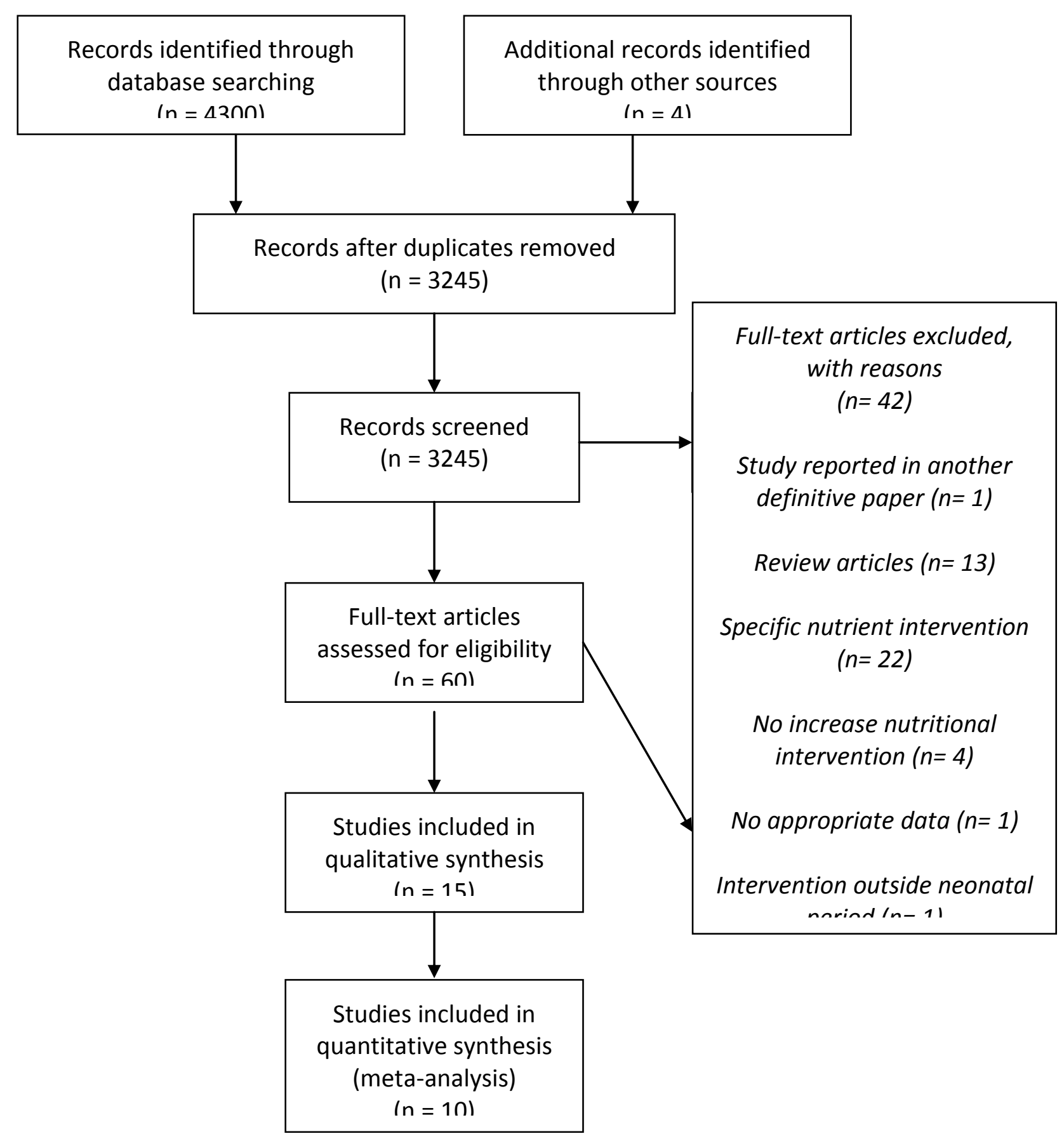

Figure 1. Flow chart of review process

This article is protected by copyright. All rights reserved. 
Fig. 2A

Increased nutrition Standard nutrition

Mean Difference

Mean Difference

Study or Subgroup Mean SD Total Mean SD Total Weight IV, Random, 95\% C

Random, $95 \% \mathrm{Cl}$

\begin{tabular}{|c|c|c|c|c|c|c|c|c|}
\hline \multicolumn{9}{|l|}{ 2.16.1 RCT } \\
\hline $\begin{array}{l}\text { Blanco } 2012 \\
\text { Subtotal }(95 \% \mathrm{Cl})\end{array}$ & 73 & 15 & $\begin{array}{l}16 \\
16\end{array}$ & 84 & 11 & $\begin{array}{l}16 \\
16\end{array}$ & $\begin{array}{l}11.9 \% \\
11.9 \%\end{array}$ & $\begin{array}{l}-11.00[-20.11,-1.89] \\
-11.00[-20.11,-1.89]\end{array}$ \\
\hline \multicolumn{9}{|c|}{$\begin{array}{l}\text { Heterogeneity: Not applicable } \\
\text { Test for overall effect: } Z=2.37(P=0.02)\end{array}$} \\
\hline \multicolumn{9}{|c|}{ 2.16.2 Observational study } \\
\hline Cormack 2011 & 88.1 & 15.3 & 37 & 89.7 & 23.9 & 27 & $9.7 \%$ & $-1.60[-11.87,8.67]$ \\
\hline Karakus 2010 & 83.9 & 11.4 & 28 & 86 & 10 & 40 & $27.6 \%$ & $-2.10[-7.34,3.14]$ \\
\hline $\begin{array}{l}\text { Poindexter } 2006 \\
\text { Subtotal }(95 \% \mathrm{Cl})\end{array}$ & 78.1 & 16.1 & $\begin{array}{l}158 \\
223\end{array}$ & 79 & 18.2 & $\begin{array}{l}714 \\
781\end{array}$ & $\begin{array}{l}50.9 \% \\
88.1 \%\end{array}$ & $\begin{array}{l}-0.90[-3.74,1.94] \\
-1.20[-3.63,1.23]\end{array}$ \\
\hline
\end{tabular}

$781-88.1 \%-1.20[-3.63,1.23]$

Heterogeneity: $\mathrm{Tau}^{2}=0.00 ; \mathrm{Chi}^{2}=0.16, \mathrm{df}=2(\mathrm{P}=0.92) ; \mathrm{I}^{2}=0 \%$

Test for overall effect: $Z=0.97(P=0.33)$

Total $(95 \% \mathrm{Cl})$

239

$797 \quad 100.0 \%$

$-2.50[-5.91,0.91]$

Heterogeneity: Tau $^{2}=3.84 ; \mathrm{Chi}^{2}=4.31, \mathrm{df}=3(\mathrm{P}=0.23) ; \mathrm{I}^{2}=30 \%$

Test for overall effect: $Z=1.44(P=0.15)$

Test for subqroup differences: $\mathrm{Chi}^{2}=4.15, \mathrm{df}=1(\mathrm{P}=0.04), \mathrm{I}^{2}=75.9 \%$

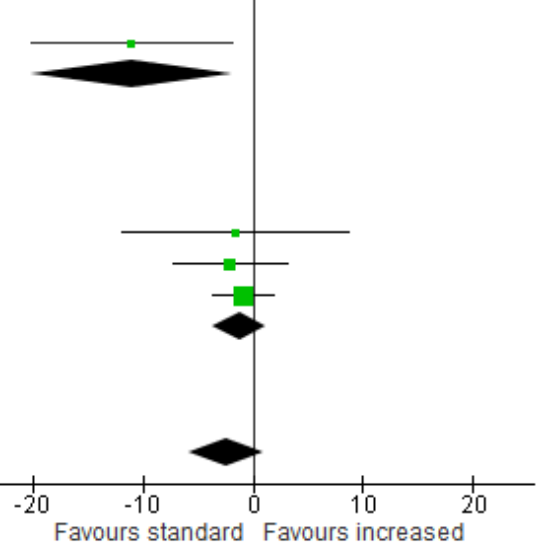

Fig. 2B

Increased nutrition Standard nutrition

Mean Difference

Mean Difference

Study or Subgroup Mean SD Total Mean SD Total Weight IV, Random, $95 \% \mathrm{Cl}$

V, Random, $95 \% \mathrm{Cl}$

$\begin{array}{lllllllll}2.10 .1 \text { RCT } & & & & & & & & \\ \text { Blanco 2012 } & 74 & 14 & 16 & 79 & 12 & 16 & 14.5 \% & -5.00[-14.03,4.03]\end{array}$

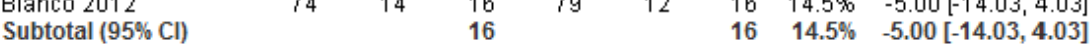

Heterogeneity: Not applicable

Test for overall effect: $Z=1.08(P=0.28)$

2.10.2 Observational study

$\begin{array}{lllllllll}\text { Cormack 2011 } & 97.5 & 9.8 & 37 & 95.4 & 11 & 27 & 26.5 \% & 2.10[-3.11,7.31]\end{array}$

$\begin{array}{lllllllll}\text { Karakus } 2010 & 94.3 & 12.5 & 22 & 86.4 & 11.1 & 40 & 22.5 \% & 7.90[1.65,14.15]\end{array}$

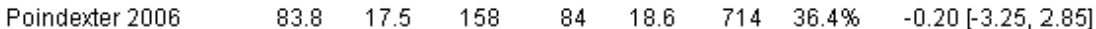

$\begin{array}{lllll}\text { Subtotal }(95 \% \mathrm{Cl}) & 217 & 781 & 85.5 \% & 2.62[-1.81,7.05]\end{array}$

Heterogeneity: $\operatorname{Tau}^{2}=9.45 ; \mathrm{Chi}^{2}=5.27, \mathrm{df}=2(\mathrm{P}=0.07) ; \mathrm{I}^{2}=62 \%$

Test for overall effect: $Z=1.16(P=0.25)$

Total $(95 \% \mathrm{Cl})$

233

$797 \quad 100.0 \% \quad 1.53[-2.65,5.72]$

Heterogeneity: $\operatorname{Tau}^{2}=10.07 ; \mathrm{Chi}^{2}=7.13, \mathrm{df}=3(\mathrm{P}=0.07) ; \mathrm{I}^{2}=58 \%$

Test for overall effect: $Z=0.72(P=0.47)$

Test for subaroup differences: $\mathrm{Chi}^{2}=2.20, \mathrm{df}=1(\mathrm{P}=0.14), \mathrm{I}^{2}=54.6 \%$

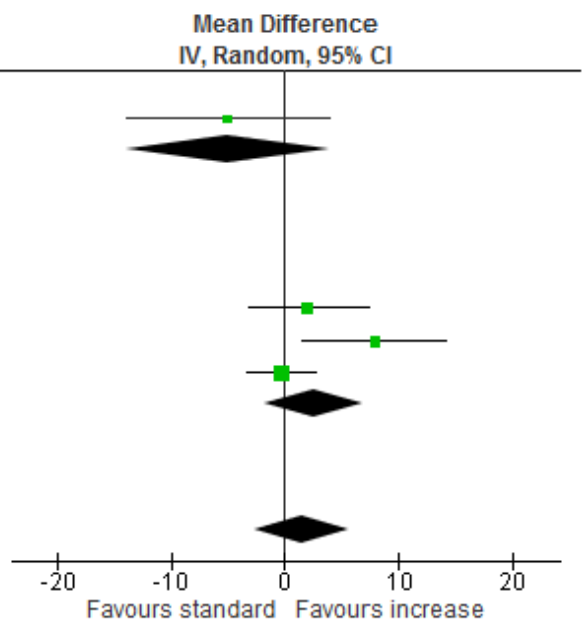

Figure 2: Forest plots for meta-analyses of differences in (a) MDI and (b) PDI scores at 12-18 months between VP and/ or VLBW infants received increased or standard parental nutrition.

This article is protected by copyright. All rights reserved. 
Fig. $3 A$

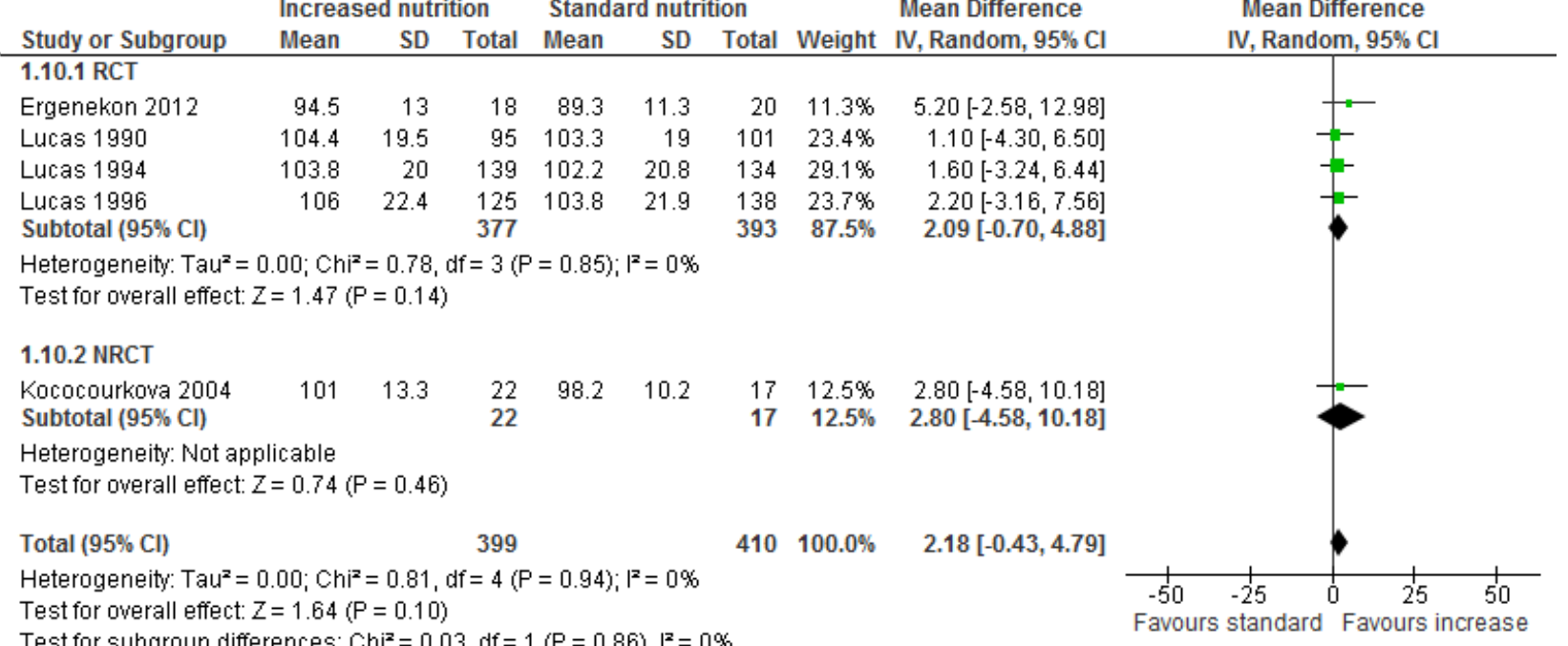

Fig. 3B

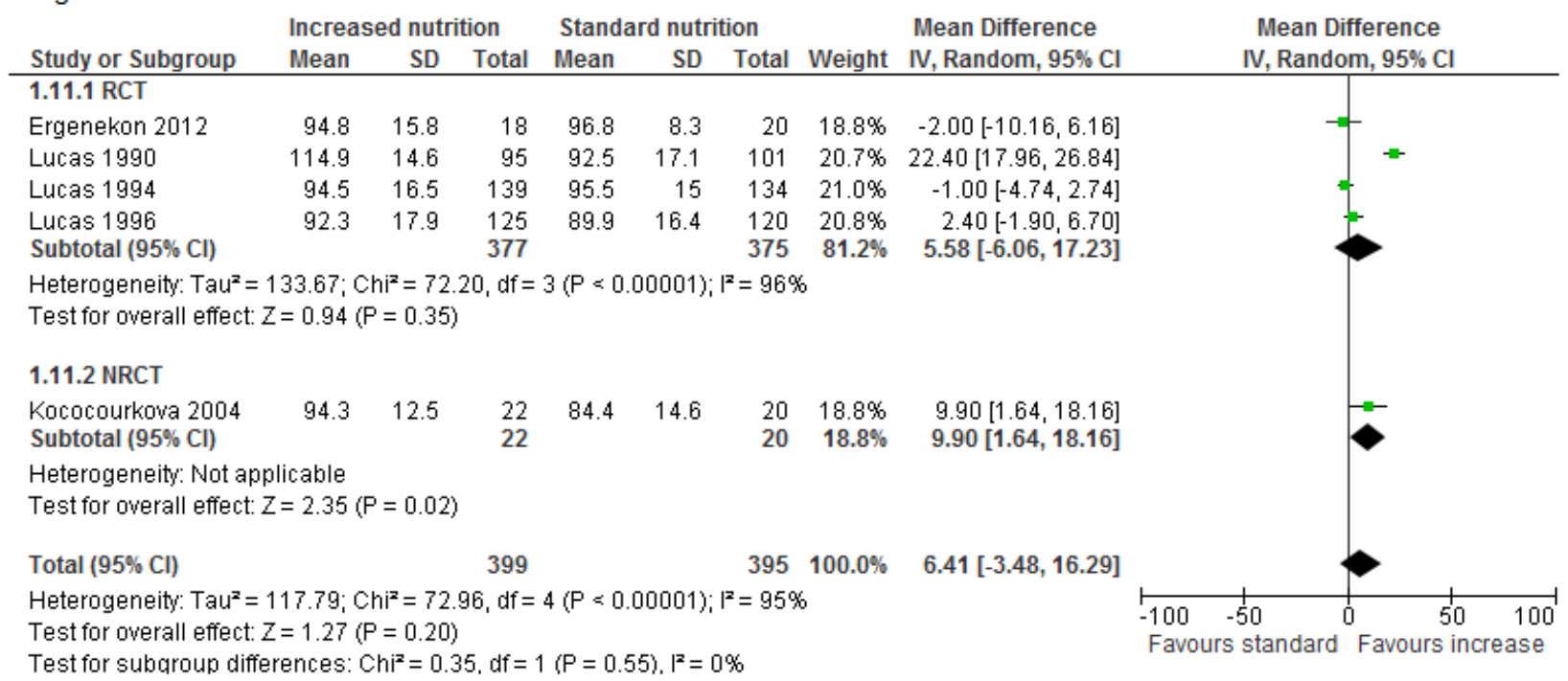

Figure 3: Forest plots for meta-analyses of differences in (a) MDI and (b) PDI scores at 12-18 months between VP and/ or VLBW infants received increased or standard enteral nutrition.

This article is protected by copyright. All rights reserved. 


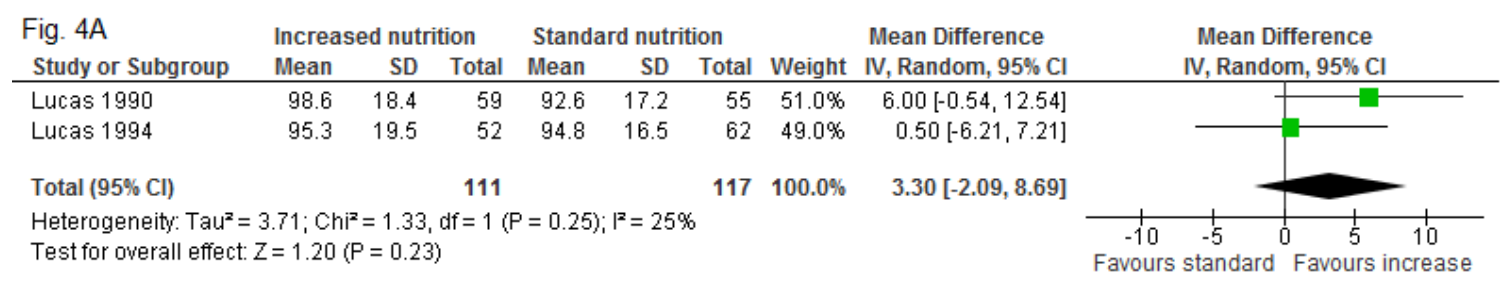

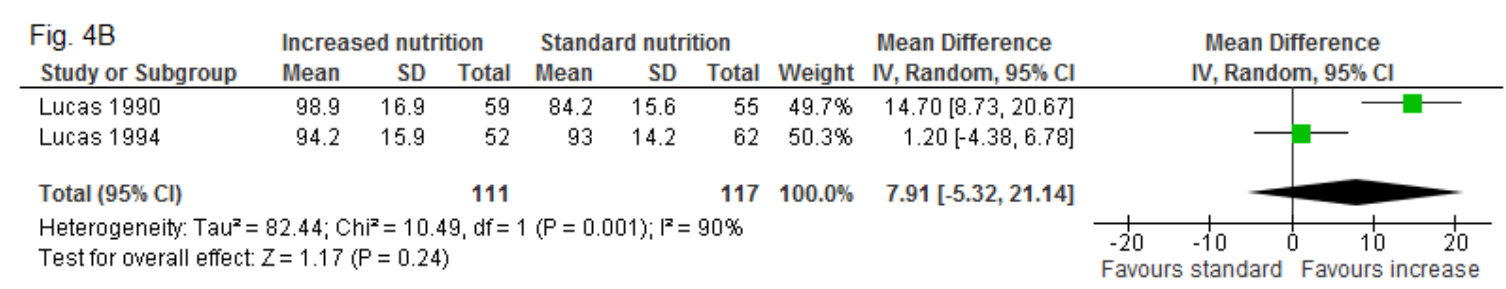

Figure 4: Forest plots for meta-analyses of differences in (a) MDI and (b) PDI scores at 12-18 months between VP and/ or VLBW infants received increased or standard sole diet. Both studies are RCTs.

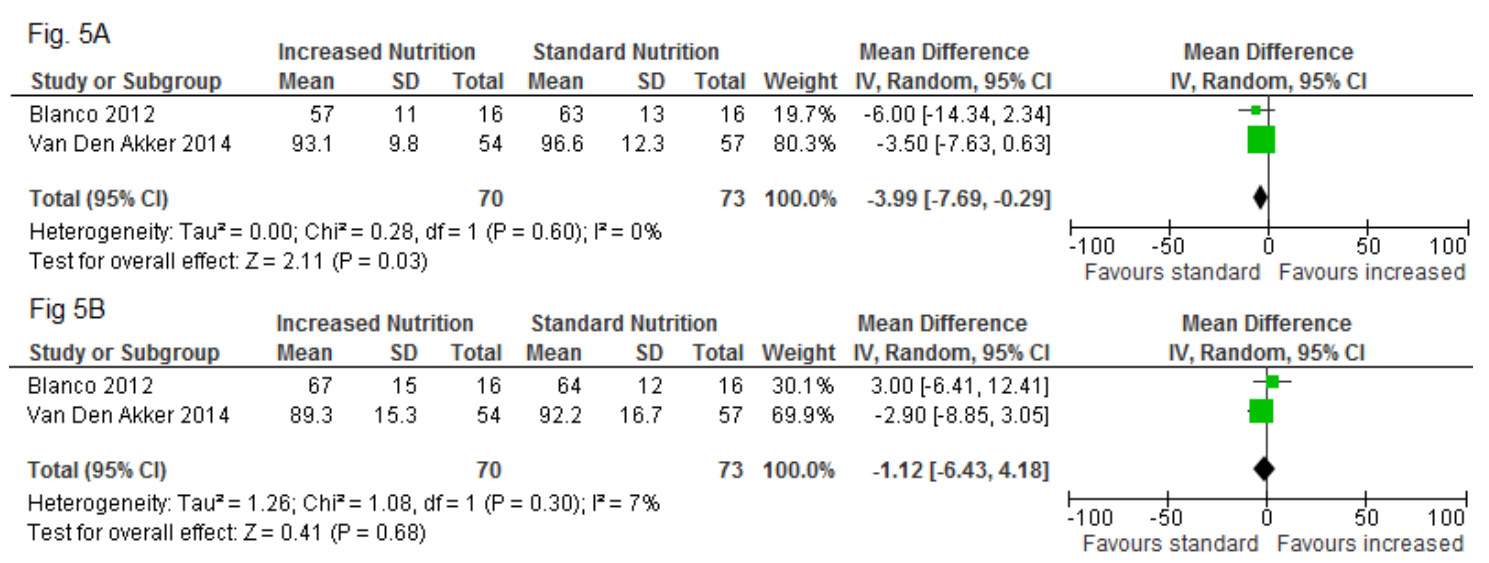

Figure 5: Forest plots for meta-analyses of differences in (a) MDI and (b) PDI scores at 24 months between VP and/ or VLBW infants received increased or standard parenteral nutrition. Both studies are RCTs.

This article is protected by copyright. All rights reserved. 


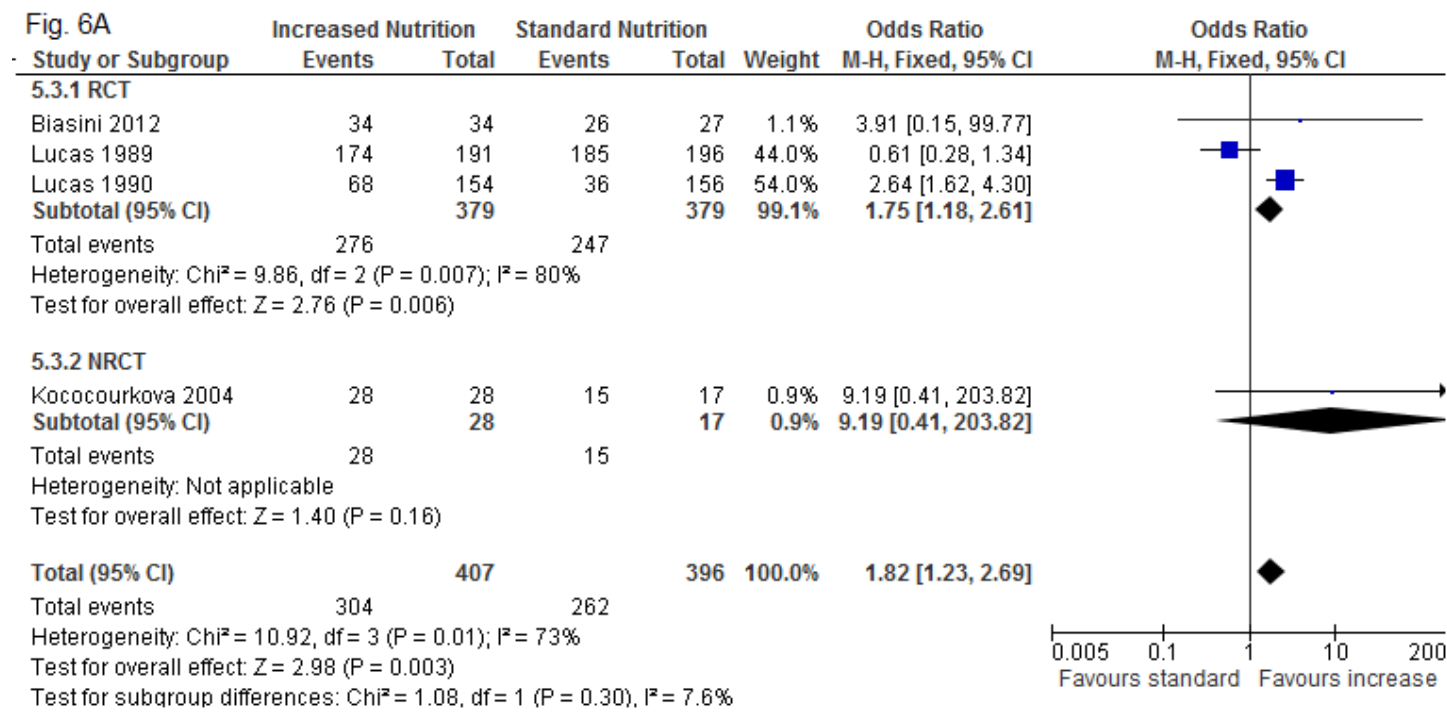

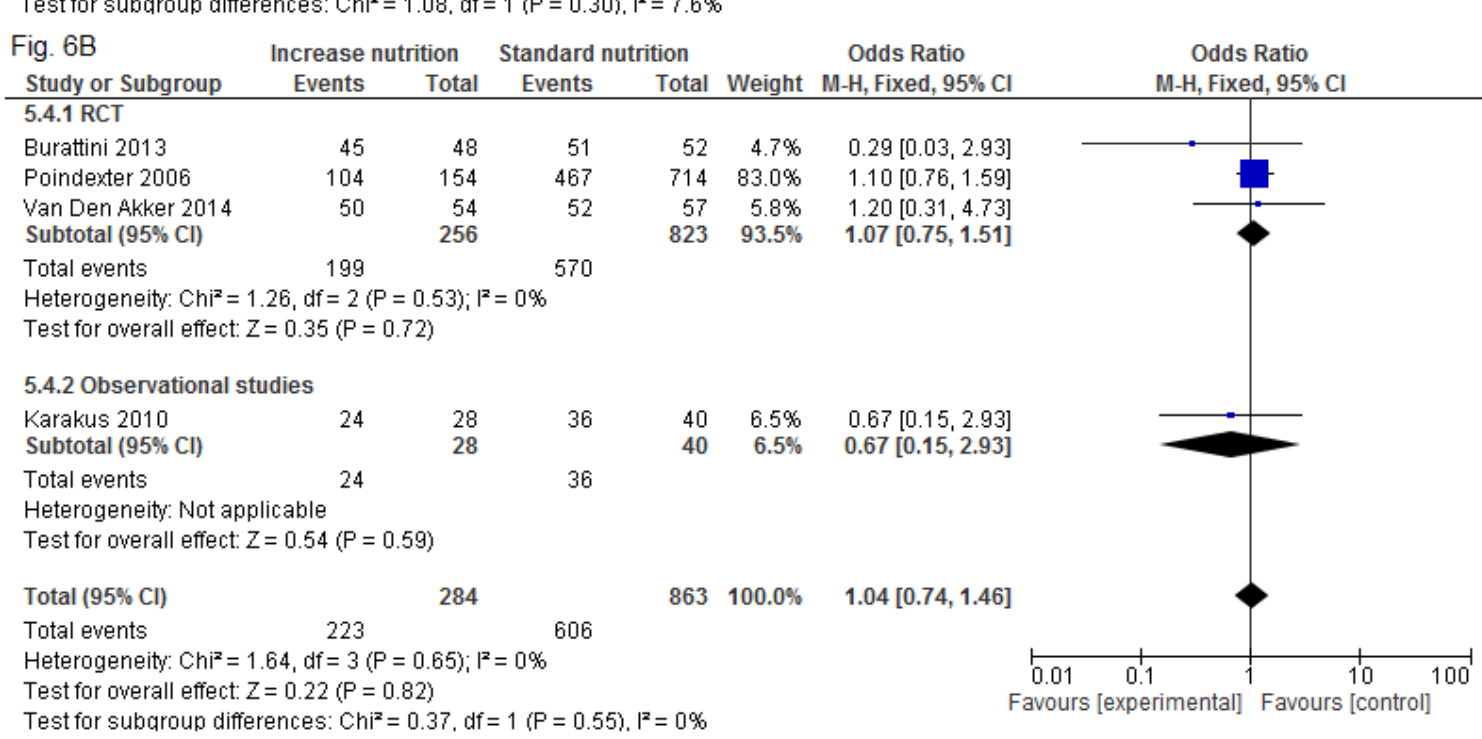

Figure 6: Forest plots for meta-analyses of differences in the survived infants without neurodevelopmental impairment in (a) enteral nutrition studies and (b) parenteral nutrition studies

This article is protected by copyright. All rights reserved. 